\title{
Pola Infeksi Oportunistik yang Menyebabkan Kematian pada Penyandang AIDS di RS Dr. M. Djamil Padang Tahun 2010- 2012
}

\author{
Aghnia Jolanda Putri ${ }^{1}$, Eryati Darwin ${ }^{2}$, Efrida ${ }^{3}$
}

\begin{abstract}
Abstrak
Infeksi oportunistik merupakan penyebab kematian utama pada 90\% penyandang AIDS (Acquired Immunodeficiency Syndrome). Peningkatan masif kematian akibat infeksi oportunistik meningkatkan angka mortalitas penyandang AIDS. Tujuan penelitian ini adalah untuk mengetahui pola infeksi oportunistik yang menyebabkan kematian pada penyandang AIDS di RS Dr. M. Djamil Padang pada tahun 2010-2012. Penelitian retrospektif dilakukan di RS Dr. M. Djamil Padang terhadap rekam medik penyandang AIDS dengan penyebab kematian infeksi oportunistik pada tahun 2010-2012. Hasil penelitian disajikan menggunakan tabel. Sebanyak 31 subyek penelitian diteliti dari jumlah total 132 penyandang AIDS rawat inap. Kelompok umur tertinggi pada subyek penelitian adalah 25-34 tahun dengan lama rawat 1-36 hari. Subyek penelitian didominasi oleh laki-laki dengan perbandingan 3:1 terhadap perempuan. Infeksi oportunistik penyerta terbanyak adalah kandidiasis oral dan tuberkulosis. Pada hasil penelitian, didapatkan infeksi oportunistik penyebab kematian pada penyandang AIDS terbanyak adalah bronkopneumonia ( 9 orang) dan yang paling sedikit adalah meningitis dan bronkitis kronis (1 orang). Mekanisme sebab kematian terbanyak adalah syok sepsis dan yang paling sedikit adalah herniasi serebri. Kesimpulan hasil studi ini menunjukkan infeksi oportunistik utama yang menyebabkan kematian pada penyandang AIDS di RS Dr. M. Djamil Padang pada tahun 2010-2012 adalah gangguan sistem respirasi seperti bronkopneumonia dan tuberkulosis. Syok sepsis merupakan mekanisme sebab kematian terbanyak.
\end{abstract}

Kata kunci: infeksi oportunistik, AIDS, kematian

\section{Abstract}

Opportunistic infections (OI) are the leading cause of death in 90\% of people living with AIDS (Acquired Immunodeficiency Syndrome). The massive increasing number of death from opportunistic infections contributes to AIDS. The study was conducted to determine distribution of opportunistic infections as cause of death to people living with AIDS in Dr. M. Djamil Padang hospital within 2010-2012. A retrospective study was conducted at Dr. M. Djamil Padang hospital towards people with AIDS whom died by opportunistic infections within 2010-2012. The results of study are presented using tables. A total of 31 subjects were selected from 132 hospitalized people with AIDS. The group age of subjects was 25-34 years old with range of length of stay 1-36 days. Subjects are dominated by men against women with 3:1 ratio. Oral candidiasis and tuberculosis is the main secondary opportunistic infections in this study. This study observed that the major opportunistic infection in people with AIDS as leading cause of death is bronchopneumonia (9 patients) and the least are meningitis (1 patient) and chronic bronchitis (1 patient). Most of death mechanisms are due to septic shock and less likely due to cerebral herniation. It can be concluded that the main opportunistic infection that causes death in people with AIDS is caused by respiratory disease such as broncopneumonia and tuberculosis. Septic shock is the leading mechanism of cause of death among all.

Keywords: opportunistic infections, AIDS, death 
Affiliasi penulis : 1. Pendidikan Dokter FK UNAND (Fakultas Kedokteran Universitas Andalas Padang), 2. Bagian Histologi FK UNAND, 3.Bagian Patologi Klinik FK UNAND

Korespondensi :Aghnia Jolanda Putri, E-mail: aghniajolandaputri@ymail.com, Telp: 085299771213

\section{PENDAHULUAN}

Infeksi oportunistik (IO) merupakan penyebab kematian utama pada penyandang AIDS (Acquired Immunodeficiency Syndrome) dengan persentase 90\%. ${ }^{1}$ Pada tahun 2005, infeksi oportunistik yang dominan muncul pada penyandang AIDS ialah tuberkulosis paru $(50 \%)$, hepatitis $(30 \%)$, kandidiasis $(25 \%)$, pneumonia (33\%), diikuti oleh diare kronis, dan tuberkulosis ekstra paru. ${ }^{2}$ Beberapa faktor yang mempengaruhi timbulnya 10 pada pasien AIDS ialah status gizi, kadar sel T CD4+, faktor risiko penularan, jenis kelamin dan rentang usia. $^{3}$ Terapi penanggulangan AIDS masih terbatas pada pencegahan kematian dengan mengurangi risiko infeksi oportunistik. Jumlah penyandang HIV/AIDS (Human Immunodeficiency Virus / Acquired Immuno deficiency Syndrome) semakin meningkat dan menjadi pandemi global. Joint/United Nations Programme on HIV/AIDS (UNAIDS) melaporkan terdapat sekitar 34 juta individu terinfeksi HIV dan 8 juta individu menyandang AIDS di dunia pada tahun 2012. Di Indonesia, terdapat 39.434 penyandang AIDS hingga tahun 2012, sedangkan di Sumatera Barat terdapat 788 penyandang AIDS pada tahun 2012. ${ }^{4}$ Jumlah kematian akibat AIDS di dunia pada tahun 2006 ialah sekitar 2,6 juta. ${ }^{5}$ Angka mortalitas penyandang AIDS di Indonesia adalah 7.293 hingga September 2012. Selain itu, sekitar 715 penyandang AIDS meninggal dunia di Sumatera Barat pada tahun 2010. Kematian penyandang AIDS tidak kunjung mencapai angka nol dan menjadi lima besar penyebab mortalitas pada anak dan dewasa di dunia. Penyakit AIDS merupakan tahapan akhir dari kumpulan gejala atau penyakit yang disebabkan oleh menurunnya kekebalan tubuh akibat infeksi HIV. ${ }^{6}$ Kondisi penurunan sistem imun pada penyandang AIDS terjadi akibat destruksi sel T CD4+ yang memiliki afinitas tinggi terhadap HIV. Virus ini akan menempel pada sel limfosit $T$ karena terdapat reseptor CD4+ terhadap gp 120 pada permukaan luar HIV. $^{7}$ Penyebab kematian pada penyandang AIDS adalah penurunan sistem imunitas secara progresif sehingga infeksi oportunistik dapat muncul dan berakhir pada kematian. Infeksi oportunistik muncul dengan bentuk infeksi baru oleh mikroorganisme lain (bakteri, fungi dan virus) atau reaktivasi infeksi laten yang dalam kondisi normal dapat dikontrol oleh sistem imun sehingga tidak menimbulkan manifestasi. Munculnya infeksi oportunistik mengindikasikan adanya efek pada imunitas yang dimediasi sel akibat imunodefisiensi dan berhubungan dengan jumlah sel $\mathrm{T}$ CD4+. ${ }^{8}$ Disebutkan dalam penelitian tersebut bahwa infeksi oportunistik merupakan penyebab kematian utama pada penyandang AIDS. Oleh karena itu perlu dilakukan penelitian terhadap infeksi oportunistik yang menyebabkan kematian pada penyandang AIDS.

\section{METODE}

Penelitian ini bersifat observasi retrospektif untuk mengetahui pola infeksi oportunistik yang menyebabkan kematian pada penyandang AIDS. Penelitian dilakukan di bagian rekam medik RS Dr. M. Djamil Padang dengan cara mengobservasi status rekam medik penyandang AIDS yang diketahui penyebab kematiannya. Populasi dan sampel penelitian adalah data rekam medik penyandang AIDS yang dirawat di RS Dr. M. Djamil Padang yang meninggal akibat infeksi oportunistik dalam periode 2010-2012. Data diambil dengan melihat sebab kematian yang tertera pada Lembar Sebab Kematian. Data penelitian disajikan dalam bentuk tabel dengan hasil pengelompokan pertahun; 2010, 2011, dan 2012. Penyebab kematian akibat infeksi oportunistik kemudian dikelompokkan sesuai sistem tubuh yang dikenai. Adapun data yang diambil sebagai bahan penelitian, yaitu tanggal masuk, tanggal keluar (meninggal), lama rawatan, nomor rekam medik, umur, penyebab kematian, infeksi oportunistik penyebab kematian, infeksi oportunistik penyerta dan keterangan tambahan terkait keadaan non-infeksi. Analisis univariat digunakan untuk mengetahui frekuensi dan distribusi infeksi oportunistik penyebab kematian penyandang AIDS.

\section{HASIL}

Dari penelitian yang dilakukan, didapatkan jumlah penyandang HIV/AIDS rawat inap di RS Dr. M. Djamil Padang pada tahun 2010 sebanyak 89 
penyandang, tahun 2011 sebanyak 87 penyandang, dan tahun 2012 sebanyak 136 penyandang. Terdapat 31 kematian pada tahun 2010, 46 kematian pada tahun 2011, dan 38 kematian pada tahun 2012.

\section{Karakteristik Subyek Penelitian}

Dari penelitian yang dilakukan, didapatkan jumlah penyandang HIV/AIDS rawat inap di RS Dr. M. Djamil Padang pada tahun 2010 sebanyak 89 penyandang, tahun 2011 sebanyak 87 penyandang, dan tahun 2012 sebanyak 136 penyandang. Terdapat 31 kematian pada tahun 2010, 46 kematian pada tahun 2011, dan 38 kematian pada tahun 2012.Setelah dilakukan pemilihan subyek penelitian berdasarkan kriteria yang telah ditentukan, didapatkan 31 penyandang yang memenuhi kriteria untuk dijadikan sampel pada penelitian ini. Adapun kelompok umur tertinggi pada subyek penelitian adalah 25-34 tahun dengan lama rawat 1-36 hari. Laki-laki lebih banyak dibanding perempuan dengan perbandingan 3:1.

Mekanisme Sebab Kematian Utama pada Penyandang AIDS dengan Infeksi Oportunistik di RS Dr M Djamil Padang Tahun 2010-2012

Mekanisme sebab kematian pada penyandang AIDS di RS Dr. M. Djamil Padang tahun 2010-2012 adalah syok sepsis (17 penyandang), diikuti gagal napas (delapan penyandang), penurunan kesadaran (lima penyandang), dan herniasi serebri (satu penyandang).

Pola Infeksi Oportunistik Penyebab Kematian Penyandang AIDS dan Sistem yang Dikenai di RS Dr. M. Djamil Padang Tahun 2010-2012

Distribusi infeksi oportunistik penyebab kematian pada penyandang AIDS adalah bronco pneumonia ( sembilan penyandang), tuberkulosis (enam penyandang), toksoplasmosis serebri (enam penyandang), gastroenteritis (empat penyandang), peritonitis tuberkulosis (dua penyandang), tuberkulosis miliar (dua penyandang), meningitis (satu penyandang), dan bronkitis kronis (satu penyandang). Distribusi sistem yang dikenai sebagai penyebab kematian penyandang AIDS di RS Dr. M. Djamil Padang Tahun 2010-2012 adalah sistem respirasi (16 penyandang), gastrointestinal (tujuh penyandang), sistemik (dua penyandang) dan neurologi (enam penyandang). Distribusi infeksi oportunistik ada pada Tabel 1.

Tabel 1. Infeksi Oportunistik Penyebab Kematian pada Penyandang AIDS di RS Dr. M. Djamil Tahun 20102012

\begin{tabular}{|c|c|c|c|c|c|}
\hline \multirow{2}{*}{$\begin{array}{c}\text { Sebab } \\
\text { Kematian }\end{array}$} & \multirow{2}{*}{$\begin{array}{l}\text { Sistem yang } \\
\text { Dikenai }\end{array}$} & \multirow{2}{*}{$\begin{array}{l}\text { Infeksi } \\
\text { Oportunistik }\end{array}$} & \multicolumn{3}{|c|}{ Jumlah } \\
\hline & & & 2010 & 2011 & 012 \\
\hline \multirow{11}{*}{$\begin{array}{l}\text { Syok } \\
\text { Sepsis }\end{array}$} & Respirasi & Bronkopneu- & 3 & 3 & 3 \\
\hline & & monia & & & \\
\hline & & Tuberkulosis & 1 & 1 & 0 \\
\hline & & Paru & & & \\
\hline & Sistemik & Tuberkulosis & 1 & 1 & 0 \\
\hline & & Miliar & & & \\
\hline & $\begin{array}{l}\text { Gastrointes- } \\
\text { tinal }\end{array}$ & $\begin{array}{l}\text { Gastroente- } \\
\text { ritis Kronis }\end{array}$ & 1 & 2 & 0 \\
\hline & & Gastroente- & 1 & 0 & 0 \\
\hline & & ritis Akut & 1 & 1 & 0 \\
\hline & & Peritonitis & & & \\
\hline & & Tuberkulosis & & & \\
\hline $\begin{array}{l}\text { Penuru- } \\
\text { nan }\end{array}$ & Neurologi & $\begin{array}{l}\text { Toksoplas- } \\
\text { mosis Serebri }\end{array}$ & 2 & 2 & 2 \\
\hline \multicolumn{6}{|l|}{$\begin{array}{l}\text { Kesada- } \\
\text { ran }\end{array}$} \\
\hline Herniasi & Neurologi & Meningitis & 1 & 0 & 0 \\
\hline \multicolumn{6}{|l|}{ Serebri } \\
\hline Gagal & Respirasi & Tuberkulosis & 0 & 2 & 2 \\
\hline \multirow[t]{4}{*}{ Napas } & & Paru & 0 & 1 & 0 \\
\hline & & Bronkitis & & & \\
\hline & & Kronis & & & \\
\hline & & Total & 11 & 13 & 7 \\
\hline
\end{tabular}

Infeksi Oportunistik Penyerta pada Penyandang AIDS di RS Dr M Djamil Padang Tahun 2010-2012

Infeksi oportunistik penyerta yang didapatkan adalah kandidiasis oral (24 penyandang), tuberkulosis (sembilan penyandang), gastroenteritis (enam penyandang), bronkopneumonia (empat penyandang), hepatitis C (satu penyandang), (satu penyandang) dan stomatitis (satu penyandang).

\section{PEMBAHASAN}

Dari 115 penyandang AIDS yang meninggal, rekam medik yang memenuhi syarat penelitian sebanyak 31 buah. Hal ini diakibatkan oleh tidak lengkapnya pengisian data rekam medik pada Lembar Sebab Kematian. Terdapat peningkatan signifikan terhadap angka kejadian HIV/AIDS sejak tahun 2011 yang diikuti penurunan angka kematian dibanding tahun sebelumnya. Lama rawat pada penyandang 
AIDS berkisar antara 1-36 hari. Di salah satu rumah sakit di Jawa Timur, rata-rata lama rawat pada penyandang AIDS adalah 9 hari dengan diagnosis infeksi oportunistik rata-rata satu pada penyandang dan terbanyak adalah kandidiasis oral dan gastroenteritis. ${ }^{6}$ Lama rawat didasari oleh banyaknya infeksi oportunistik yang timbul pada tiap penyandang dan tingkat keparahan terkait dengan identifikasi dini. Peningkatan jumlah penyandang AIDS merupakan akibat dari tingkat perilaku berisiko yang cukup aktif menularkan di dalam sub-populasi tertentu. Hal ini mengakibatkan jumlah kasus HIV dan AIDS terus meningkat tiap tahunnya meski upaya preventif terus dilaksanakan. Dilain hal, penurunan angka kematian pada penyandang AIDS terjadi di beberapa kota besar dengan fasilitas kesehatan yang telah memadai seperti Jakarta, Semarang, Yogyakarta, dan Makassar. Penurunan angka kematian HIV/AIDS sangat dipengaruhi oleh terapi medis, yaitu pemberian terapi antiretroviral pada waktu dan regimen yang tepat, ketersediaan obat antiretroviral, serta layanan komprehensif berkesinambungan pada fasilitas kesehatan. $^{8}$

\section{Karakteristik Subyek Penelitian}

Kelompok umur tertinggi pada penyandang AIDS dengan infeski oportunistik berada pada kisaran 20-39 tahun $^{9}$ dan 27-35 tahun. ${ }^{10}$ Penyandang AIDS dengan infeksi oportunistik lebih banyak pada laki-laki dibanding perempuan dengan rasio 3:1. Didapatkan kelompok jenis kelamin yang terbanyak adalah lakilaki sejumlah 214 orang $(80,75 \%)$ diikuti perempuan 51 orang (19,25\%). Hal ini dipengaruhi dengan tingginya prevalensi risiko penyebab HIV/AIDS pada kelompok umur ini seperti perilaku seks bebas, penggunaan jarum suntik bersama, dan faktor risiko lainnya.

\section{Mekanisme Sebab Kematian Penyandang AIDS diRS Dr. M. Djamil Padang Tahun 2010-2012 \\ Berdasarkan penelitian yang dilakukan, sebab kematian oleh infeksi oportunistik yang ditemukan pada penyandang AIDS RS Dr. M. Djamil Padang terbanyak disebabkan oleh syok sepsis (17 penyandang), diikuti gagal napas (delapan penyandang), penurunan kesadaran (lima}

penyandang), herniasi serebri (satu penyandang). Sebab kematian akibat AIDS bervariasi. Adapun sebab kematian lain ialah keganasan $(11,8 \%)$, infeksi non-AIDS (8,2\%), penyakit kardiovaskular (7,9\%), kekerasan $(7,8 \%)$ seperti bunuh diri, penyalahgunaan obat-obatan, kecelakaan dan sebagainya. ${ }^{11}$ Pada penyandang AIDS dengan infeksi oportunistik, mekanisme sebab kematian utama adalah syok sepsis akibat bakteri seperti broncopneumonia. ${ }^{12}$ Sepsis merupakan faktor risiko independen yang berhubungan dengan kematian dan telah menjadi penyebab masuknya penyandang AIDS ke Unit Pelayanan Intensif. Disfungsi kekebalan pada penyandang AIDS mempengaruhi tingkat biomarker inflamasi, protein C-reaktif (CRP), IL-6, IL-10 dan procalcitonin (PCT). Respons inflamasi berlebihan dan deregulasi memainkan peran kunci dalam pengembangan beberapa disfungsi organ pada sepsis. Namun, respons ini didapati terutama dalam sepsis bakteri dan kurang ekspresif dalam virus dan jamur. Infeksi HIV akut dan kronis memicu pelepasan mediator inflamasi dan sitokin. Peningkatan kadar aktivasi sel T CD38+, aktivasi monosit yang dipengaruhi lipopolisakarida bakteri, pengurangan kadar sel T CD4+ menyebabkan keadaan inflamasi persisten dengan kadar sitokin tinggi akibat sistem respons imun bawaan. ${ }^{13}$

Pola Infeksi Oportunistik Penyebab Kematian Penyandang AIDS dan Sistem yang Dikenai di RS Dr. M. Djamil Padang Tahun 2010-2012

Pada penelitian ini didapatkan data mengenai distribusi infeksi oportunistik yang menyebabkan kematian pada penyandang AIDS di RS Dr. M. Djamil Padang pada tahun 2010-2012. Dalam periode tersebut, infeksi oportunistik penyebab kematian pada penyandang AIDS adalah bronkopneumonia (sembilan penyandang), tuberkulosis (enam penyandang), toksoplasmosis serebri (enam penyandang), gastroenteritis (empat penyandang), peritonitis tuberkulosis (dua penyandang), tuberkulosis miliar (dua penyandang), meningitis (satu penyandang), bronkitis kronis (satu penyandang). Pada tahun 2010 dan 2011 syok sepsis akibat broncopneumonia menyebabkan kematian pada penyandang AIDS terbanyak. Sedangkan, pada tahun 2012, infeksi 
oportunistik penyebab kematian terbanyak adalah toksoplasmosis serebri dan tuberkulosis paru.

Penelitian mengenai proporsi infeksi oportunistik juga telah dilakukan oleh Elona di RSUP Haji Adam Malik Medan pada tahun 2010. Penelitian tersebut menemukan kelompok infeksi oportunistik penyebab kematian pada 265 penyandang AIDS diantaranya tuberkulosis 86 orang $(21,77 \%)$, diare Cryptosporidia sejumlah 47 orang (11,90\%), Pneumocystis pneumonia 11 orang (2,84\%), diikuti Toksoplasmosis lima orang $(1,26 \%){ }^{9}$ Selain itu, berdasarkan penelitian yang dilakukan terhadap 331 pasien di Chiang Rai, Thailand Utara, penyebab utama kematian penyandang AIDS adalah tuberkulosis dengan persentase sebesar 39,3\%, infeksi oportunistik lain 28,4\%, penyakit sistemik lain sebesar $16,3 \%$, dan penyebab lain 16\%. Diantara kematian dengan tuberkulosis, sebanyak 36,9\% kematian diakibatkan tuberkulosis paru, sedangkan sisanya akibat tuberkulosis ekstra paru atau keduanya. ${ }^{14}$ Penelitan lain juga dilakukan di Ambajogai Medical and Hospital India pada 178 penyandang juga mengungkapkan bahwa infeksi oportunistik penyebab kematian utama adalah tuberkulosis (59\%) dan gastroenteritis akut (18\%). Berdasarkan studi yang dilakukan oleh WHO (2010) terhadap HAART (Highly Active Anti-Retroviral Therapy), tingginya insiden infeksi oportunistik penyebab kematian akibat tuberkulosis diakibatkan oleh penggunaan antiretroviral yang terlambat dan tingginya prevalensi HIV di suatu daerah. Semakin tinggi prevalensi HIV di suatu daerah, semakin tinggi juga prevalensi koinfeksi HIV-TB pada penderita HIV di daerah tersebut. Selain itu, pengonsumsian ART dan Obat Anti Tuberkulosis (OAT) secara bersamaan menimbulkan efek samping yang dapat memperparah kondisi penyandang dan menyebabkan kematian. ${ }^{15}$

Pneumonia Pneumocystis Carinii (PCP) merupakan infeksi oportunistik yang sering dijumpai dan menyebabkan kematian pada penyandang AIDS $(80 \%) .{ }^{16}$ Penyandang AIDS dengan inisiasi terapi saat kadar sel T CD4+ kurang dari $100 \mathrm{sel} / \mu \mathrm{L}$ memiliki risiko tinggi terhadap insiden PCP. Pneumonia juga merupakan infeksi oportunistik terbanyak penyebab kematian penyandang AIDS sesuai dengan penelitian. ${ }^{17}$ Penelitian dilakukan selama 16 bulan dengan 16 penyandang meninggal akibat pneumonia bakterialis. Penyandang AIDS tersebut tidak mengonsumsi ART secara kontinyu dan merupakan perokok. Merokok merupakan faktor risiko utama dengan risiko pneumonia bakterialis $80 \%$ lebih tinggi dibanding dengan yang bukan perokok. Studi menunjukkan insiden pneumonia nosokomial (Hospital Acquired Pneumonia) merupakan pneumonia bakterialis utama pada penyandang AIDS. Studi retrospektif dilakukan pada penyandang HIV/AIDS di Infectious Diseases Clinic of Milan pada tahun 19882002. Mikroorganisme utama penyebab pneumonia nosokomial adalah Pseudomonas aeruginosa (33\%) Staphylococcus aureus (25\%) dan Streptococcus pneumoniae (21\%). Angka kematian sebesar 25,8\% dengan penyebab utama resistensi terhadap metisilin. $^{18}$

Infeksi Oportunistik Penyerta pada Penyandang AIDS di RS Dr M Djamil Padang Tahun 2010-2012

Kandidiasis oral merupakan infeksi oportunistik penyerta terbanyak dengan 24 penyandang, diikuti oleh tuberkulosis sebanyak 9 penyandang. Hal ini sesuai dengan penelitian yang dilakukan Merati di RS Dr. Cipto Mangunkusumo. Dari 698 subyek yang diteliti, infeksi oportunistik terbanyak adalah kandidiasis oral (40\%), diikuti tuberkulosis $(37,1 \%)$, diare kronis $(27,1 \%)$, pneumonia bakterialis $(16,7 \%)$, toksoplasmosis serebri (12\%) dan infeksi Herpes zooster (6\%). ${ }^{14}$

Kandidiasis oral merupakan manifestasi infeksi oportunistik terbanyak pada penyandang HIV/AIDS. ${ }^{19}$ Infeksi ini terutama disebabkan oleh Candida albicans, organisme jamur dimorfik yang terdapat dalam rongga mulut dalam keadaan nonpatogen. Organisme ini memiliki kemampuan untuk berubah menjadi patogen dengan bentuk hifa. Kondisi yang mendukung transformasi ini diantaranya adalah disfungsi kekebalan tubuh. Imunitas selular dan humoral berperan dalam menjaga $C$. albicans di sebagai organisme komensal. Gangguan pada leukosit polimorfonuklear menyebabkan kerentanan infeksi secara sistemik, sedangkan gangguan pada imunitas selular yang diregulasi oleh sel T CD4+ mengurangi perlindungan terhadap infeksi mukosa. Terdapat korelasi penurunan jumlah sel T CD4+ 
dengan timbulnya kandidiasis oral karena mempengaruhi kebutuhan ambang sel T CD4+ sistemik untuk melindungi mukosa mulut serta status imunitas lokal. Onset kandidiasis oral dipengaruhi oleh kadar sel T CD4+, penurunan sebesar $25 \%$ dari kadar normal telah dapat menimbulkan manifestasi dan mempengaruhi progresifitas penyakit. ${ }^{20}$

\section{Keterbatasan Penelitian}

Kurangnya kasus yang ikut serta dalam penelitian ini disebabkan oleh ketidaklengkapan data medik yang diinginkan dalam berkas medik yang diobservasi. Hal ini mengurangi jumlah sampel penelitian dan dikhawatirkan tidak mewakili populasi penelitian ini. Selain itu, penelitian ini tidak melakukan pencatatan data sosial ekonomi secara lengkap untuk mengetahui faktor risiko penyandang.

\section{KESIMPULAN}

Infeksi oportunistik penyebab kematian pada penyandang AIDS di RS Dr. M. Djamil Padang pada tahun 2010-2012 terbanyak adalah bronkopneumonia dan yang paling sedikit adalah meningitis dan bronkitis kronis.

Sistem yang terlibat sebagai penyebab kematian penyandang AIDS di RS Dr. M. Djamil Padang Tahun 2010-2012 dengan infeksii oportunistik terbanyak adalah sistem respirasi, diikuti sistem neurologi dan gastrointestinal.

Mekanisme sebab kematian pada penyandang AIDS di RS Dr. M. Djamil Padang tahun 20102012 terbanyak adalah syok sepsis dan yang paling sedikit adalah herniasi serebri.

\section{UCAPAN TERIMA KASIH}

Penulis mengucapkan terima kasih kepada Taufik atas bantuannya selama penulis melakukan penelitian di Rekam Medik RS Dr. M. Djamil Padang.

\section{DAFTAR PUSTAKA}

1. Onyancha B. An informetric investigation of the relatedness of opportunistic infections to HIV/AIDS. Information Processing and Management. 2005; 41(1):1573-88.
2. Astoro N, Djauzi S, Djoerban Z, Prodjosudjadi W. Kualitas hidup penderita HIV dan faktor-faktor yang mempengaruhi. Jakarta: Balai Penerbit FKUI; 2003.

3. Sudoyo AW, Setiyohadi B, Alwi I, Simadibrata M, Setiati S. Buku ajar ilmu penyakit dalam. Edisi ke5. Jakarta: Interna Publishing; 2009.

4. Ditjen PP dan PL Kemenkes RI. Statistik kasus HIV/ AIDS di Indonesia. Jakarta: Kemenkes RI; 2012.

5. Kurniasih N, et al. Situasi HIV/AIDS di Indo-nesia Tahun 1987-2006. Jakarta: Depkes RI; 2006.

6. Djoerban Z, Djauzi S. HIV/ AIDS di Indonesia. Dalam: Buku ajar ilmu penyakit dalam. Jakarta: Interna Publishing; 2009.

7. Jawetz E. Medical microbiology and immunology: examination and board review. USA: McGraw-Hill; 2003.

8. Pohan HT. Opportunistic infection of HIVinfected/AIDS patients in Indonesia: problems and challenge. Acta Med Indonesia. 2006; 38(1):13551.

9. Elona F. How HIV affect your body. AIDS. 2010; 12(2):756-68.

10. Madkar S. Spectrum of opportunistic infections in HIV/AIDS patients. Indian Journal of Community Health. 2010;24(3):184-90.

11. May M. Causes of death in HIV-1 infected patients treated with antiretroviral therapy. 1996-2006: collaborative analysis of 13 HIV cohort studies. Clinical Infectious Disease. 2010;50(10):1387-96.

12. Lewden S. Causes of death among human immunodeficiency virus (HIV) infected adults in the era of potent antiretroviral therapy: emerging role of hepatitis and cancers, persistent role of AIDS. International Journal of Epidemiology. 2005;34(1); 121-30.

13. Silva JM. Sepsis in AIDS patients: clinical, etiological and inflammatory characteristics. Journal of International AIDS Society. 2013; 16(1): 1123-9.

14. Merati T. Respons imun infeksi HIV. Dalam: Buku Ajar IImu Penyakit Dalam. Jakarta: Interna Publishing; 2009. 
15. Kantipong P. Cause of mortality among tuberculosis and HIV coinfected patients in Chiang Rai, Northern Thailand. HIV/AIDS Research and Palliative Care. 2012;4:159-68.

16. Nasronudin. Pendekatan biologi, molekuler, klinis, dan sosial HIV dan AIDS. Surabaya: Airlangga University Press; 2007.

17. Tupan T. Penularan dan pencegahan AIDS di Indonesia. BACA. 1996;21(5):1-8.

18. Gordin F, Roediger M. Pneumonia in HIV-infected persons: increased risk with cigareette smoking and treatment interruption. American Journal of Respiratory and Critical Care Medicine. 2008; 178(1):630-6.

19. Franzetti F. Nosocomial bacterial pneumonia in HIV-infected patients: risk factors for adverse outcome and implications for rational empiric antibiotic therapy. Infections. 2006;34(1):9-16.

20. Vargas K. Carriage frequency, intensity of carriage, and strains of oral yeast species vary in the progression to oral candidiasis in human immunodeficiency virus-positive individuals. J Clin Microbiol. 2002;40:341-50. 